\title{
Cyanobionts from the coralloid roots of Cycadales: is there any molecular evidence of cyanotoxins?
}

\author{
Ana L. Pereira ${ }^{1, *}$, Tiago Parente $^{1}$ and Vitor Vasconcelos ${ }^{1,2}$ \\ ${ }^{1}$ Interdisciplinary Centre of Marine and Environmental Research (CIIMAR/CIMAR), University of Porto, Rua \\ dos Bragas 289, P 4050-123 Porto, Portugal. \\ 2 Department of Biology, Faculty of Sciences of the University of Porto, Rua do Campo Alegre, 4069-007 Porto, \\ Portugal. \\ * Corresponding author: anapereira271268@yahoo.com
}

Received: $12 / 12 / 2013$

Accepted: 03/02/2015

\begin{abstract}
Cyanobionts from the coralloid roots of Cycadales: is there any molecular evidence of cyanotoxins?

The gymnosperms of the order Cycadales form a symbiosis with cyanobacteria in a special zone of the coralloid roots called the cyanobacterial zone (a green ring between the inner and outer root cortex). Free-living cyanobacteria synthesise secondary metabolites, including cyanotoxic compounds. Given that cyanotoxins were synthesised by certain symbiotic cyanobacteria from lichens and from the gymnosperm Macrozamia, this study investigated the presence of genes for four cyanotoxins (microcystin, nodularin, cylindrospermopsin and saxitoxin) in the cyanobionts of Encephalartos and Cycas revoluta collected in three Portuguese botanical gardens. PCR reactions indicated that the cyanobionts did not have the genes to synthesise microcystin, nodularin and cylindrospermopsin. However, for the saxitoxin gene, three isolates (accessions fEnc1, fEH1, cEH1) showed a positive amplification with the pair of primers sxtI683F/sxt877R. The BLAST of the nucleotide sequences did indicate a homology to the $s x t$ I gene that encodes the enzyme $O$-carbamoyltransferase (OCTASE). Nevertheless, the same samples did not amplify with a second pair of primers for the sxtI gene ( $s x t \mathrm{I}-\mathrm{F} 2 / s x t \mathrm{I}-\mathrm{R})$. Most likely, this result indicates that the OCTASE enzyme is related to the synthesis of other compounds rather than saxitoxin. More research on these cyanobionts should be conducted in the future.
\end{abstract}

Key words: Cyanobionts, Cycadales, cyanotoxins, saxitoxin, microcystin, cylindrospermopsin, nodularin.

\section{RESUMEN}

Cianobiontes en raíces coraloides de Cycadales: ¿hay alguna evidencia molecular de cianotoxinas?

Las gimnospermas del Orden Cycadales forman simbiosis con las cianobacterias en una zona de las raíces coraloides llamada la zona de cianobacterias (un anillo verde entre la corteza interna y externa de la raíz). Las cianobacterias de vida libre sintetizan metabolitos secundarios que incluyen compuestos cianotóxicos. Como algunas cianobacterias simbióticas de líquenes y de la gimnosperma Macrozamia sintetizan cianotoxinas, se decidió investigar la presencia de los genes de cuatro cianotoxinas (microcistina, nodularina, cilindrospermopsina y saxitoxina) en los cianobiontes aislados de Encephalartos y Cycas revoluta recogidas en tres jardines botánicos portugueses. La amplificación de PCR indica que los cianobiontes no tienen los genes para la síntesis de la microcistina, nodularina y cilindrospermopsina. Sin embargo, para el gene de la saxitoxina, tres aislamientos ( $f E n c 1, f E H 1, c E H 1)$ mostraron una amplificación positiva con el par de cebadores sxtI683F/sxtI877R. El BLAST de las secuencias de nucleótidos indicó una homología con el gen sxtI que codifica la enzima O-carbamoiltransferasa (OCTASA). Sin embargo, las mismas muestras no mostraron amplificación con un segundo par de cebadores para el gen sxtI (sxtI-F2/sxtI-R). Este resultado probablemente apunta a que la enzima OCTASA puede estar relacionada con la síntesis de otros compuestos en lugar de la saxitoxina. Se debería ampliar la investigación con estos cianobiontes en el futuro.

Palabras clave: Cianobiontes, Cycadales, cianotoxinas, saxitoxina, microcistina, cilindrospermosina, nodularina. 


\section{INTRODUCTION}

Several free-living cyanobacteria of the genera Anabaena, Nodularia, Nostoc, Aphanizomenon and others synthesize bioactive secondary metabolites, such as the cyanotoxins (the hepatotoxins microcystin and nodularin, the neurotoxin saxitoxin and the cytotoxin cylindrospermopsin). Those substances, when released in water bodies, have adverse effects on cells or tissues after their ingestion by animals or uptake by phytoplankton, zooplankton and plants. These effects poses a health problem due to not only food web bioconcentration and bioaccumulation but also poisoning through the ingestion of contaminated food (Wiegand \& Pflugmacher, 2005; Jungblut \& Neilan, 2006; Pearson et al., 2010; Merel et al., 2013).

Several heterocystic nitrogen-fixing cyanobacteria belonging to a few genera such as Anabaena or Nostoc establish symbiotic associations with eukaryotic organisms such as sponges, fungi, and plants (bryophytes, pteridophytes, gymnosperms and angiosperms). The symbioses in plants occur in extracellular or intracellular pre-existing or newly formed anatomical structures and are non-everlasting, with a de novo infection by the cyanobacterium and formation of the partnership each time a new plant develops; the exceptions are the pteridophytes belonging to the family Azollaceae, which form a permanent symbiosis with the cyanobacterium Anabaena azollae. In those symbioses, the cyanobacterium fixes the atmospheric nitrogen into ammonia, nitrates or nitrites that can be released and absorbed by the host, and the host, in turn, provides other nutrients such as sugars as well as protection against abiotic and biotic factors (Rai et al., 2000; Usher et al., 2007).

The order Cycadales is an ancient group that occurs in tropical and subtropical regions. The order is divided into two families, Cycadaceae (only containing the genus Cycas) and Zamiaceae (with the remaining 10 genera, in which are included the genus Encephalartos) (Zonneveld, 2012). All the members of the order Cycadales form, in addition to the main root, finger-like lateral roots (called coralloid roots) that protrude from the ground or remain at a shallow depth in the soil and in which infection or colonization by the cyanobacterium occurs (Rai et al., 2000). In the coralloid roots, in a zone called the cyanobacterial ring lying between the inner and the outer root cortex (Fig. 1), inhabit filamentous heterocystous cyanobacteria. These cyanobacteria belong to several genera: Nostoc (Costa et al., 1999; Gehringer et al., 2010; Thajuddin et al., 2010; Yamada et al., 2012), Calothrix (Gehringer et al., 2010; Thajuddin et al., 2010) or Anabaena (Gehringer et al., 2010). As mentioned above, certain free-living cyanobacteria synthesise cyanotoxins, and as the majority of the symbioses are de novo infections with cyanobacteria from the surrounding environment, it can be assumed that if the cyanobacteria that form the symbiosis have the genes to synthesise cyanotoxins, those compounds could be produced during the symbiosis. However, research on cyanotoxins in cyanobionts is very recent, and current information is still scarce. Nevertheless, the microcystin (MC) variants MC-LR and MC-XR have been found in the cyanobionts of the lichens Pannaria (Oksanen et al., 2004), Peltigera, Sticta, Lobaria and Nephroma (Kaasalainen et al., 2012, 2013), and nodularin (Nod) has been detected in the cyanobionts of the lichens Sticta and Peltigera (Kaasalainen et al., 2012). In the gymnosperms, nodularin has been detected in the Nostoc symbiont of Macrozamia riedlei and M. serpentina (Gehringer et al., 2012), but the presence of these cyanotoxins in other cyanobionts associated with the Cycadales has not yet been demonstrated.

The aim of this study was to evaluate the possible presence of four cyanotoxic genes (microcystin, nodularin, cylindrospermopsin and saxitoxin) in the cyanobionts of the coralloid roots of Cycadales collected in three Portuguese botanical gardens.

\section{MATERIALS AND METHODS}

\section{Plant material}

Coralloid roots located at or a few centimetres below the soil surface were collected from the 
living collections of three Portuguese botanical gardens in northern and central mainland Portugal (Table 1). The gymnosperms from which the coralloid roots were collected belong to the order Cycadales and to the families Cycadaceae and Zamiaceae. The roots were washed and scrubbed in tap water to remove soil and stored at $4{ }^{\circ} \mathrm{C}$.

\section{Isolation and culture of the cyanobionts}

Two sets of cyanobionts from the coralloid roots were used in this research -fresh isolated cyanobionts and cultured cyanobionts in culture medium. The coralloid roots were disinfected with hydrogen peroxide ( $2 \%)$ and washed in sterile water. For the fresh isolated cyanobionts, $1 \mathrm{~cm}$ long sections of the coralloid roots were cut, the root cap peeled off and the cyanobacterial zone transferred to Eppendorf tubes, homogenised in a vortex to detach the cyanobionts and stored at $-20{ }^{\circ} \mathrm{C}$ until DNA extraction.

To culture the cyanobionts in liquid medium and under controlled conditions, the cyanobionts from coralloid roots were isolated using the method described by Gehringer et al. (2010) with some modifications. To isolate the cyanobionts, 1-mm transverse sections of sterile coralloid roots were placed on agar plates containing $\mathrm{BG}_{0}-11$ medium at pH 7.4 (Rippka et al., 1979),
$2 \%$ agar and $100 \mu \mathrm{g} / \mathrm{ml}$ cycloheximide. The plates were incubated in a culture chamber at $24{ }^{\circ} \mathrm{C}$, with a photoperiod of $16 \mathrm{~h}$ light/ $8 \mathrm{~h}$ dark and a light intensity of $40 \mu \mathrm{mol} \mathrm{m} \mathrm{m}^{-2} \mathrm{~s}^{-1}$. After 2 months, the colonies of each section were cultured in liquid $\mathrm{BG}_{0}-11$ medium containing $100 \mu \mathrm{g} / \mathrm{ml}$ cycloheximide in the same conditions described above. After the observation of the cyanobiont filaments of each isolate under a light microscope (Olympus BX41, Olympus, Lisbon, Portugal), all isolates of each gymnosperm were placed in a single culture with liquid $\mathrm{BG}_{0}-11$ without cycloheximide. Every month, the biomass was collected by centrifugation at $4600 \mathrm{rpm}\left(10 \mathrm{~min}, 4^{\circ} \mathrm{C}\right)$, and stored at $-20^{\circ} \mathrm{C}$ until DNA extraction.

\section{DNA extraction, PCR amplification and sequencing}

The DNA of both cyanobionts (freshly isolated and cultured) were extracted with the PureLink ${ }^{\circledR}$ Genomic DNA MiniKit (Invitrogen, Lisbon, Portugal) according to the manufacturer's instructions. The DNA was quantified using a Qubit@fluorometer (Invitrogen) with the Quant-iT ${ }^{\circledR}$ dsDNA HS assay following the manufacturer's instructions. The DNA was stored at $-20^{\circ} \mathrm{C}$.

Table 1. List of accession designations of cyanobionts isolated from several Cycadales collected in three Portuguese botanical gardens and used in this study. Lista de códigos de los cianobiontes aislados de varios ejemplares de Cycadales recogidos en tres jardines botánicos portugueses utilizados en este estudio.

\begin{tabular}{cccc}
\hline Accession $^{a}$ & \multicolumn{1}{c}{ Species } & Origin and year of collection & Collector \\
\hline Order Cycadales-Family Cycadaceae & Cycas revoluta & Coimbra Botanical Garden, 2012 & \\
\hline CR1 & Cycas revoluta & Tropical Botanical Garden, Lisbon, 2012 & A. L. Pereira \\
CR2 & & & \\
\hline Order Cycadales-Family Zamiaceae & Encephalartos sp. & Porto Botanical Garden, Lake Garden, 2012 & A. L. Pereira \\
\hline Enc1 & Encephalartos horridus & Coimbra Botanical Garden, 2012 & A. L. Pereira \\
EH1 & Encephalartos horridus & Tropical Botanical Garden, Lisbon, 2012 & A. L. Pereira \\
EH2 & Encephalartos paucidentatus & Tropical Botanical Garden, Lisbon, 2012 & A. L. Pereira \\
EP1 & Encephalartos villosus & Tropical Botanical Garden, Lisbon, 2012 & A. L. Pereira \\
EV1 & Encephalartos altensteinii & Tropical Botanical Garden, Lisbon, 2012 & A. L. Pereira \\
EA1 & Encephalartos lebomboensis & Tropical Botanical Garden, Lisbon, 2012 & A. L. Pereira \\
EL1 & Encephalartos lehmannii & Tropical Botanical Garden, Lisbon, 2012 & A. L. Pereira \\
ELeh1 ${ }^{b}$ & Encephalartos lehmannii & &
\end{tabular}

$a$ The accession designation of the cyanobionts was given by the manuscript authors.

${ }^{b}$ It was only possible to use the cultured cyanobiont. 
To perform the PCR reactions, the thermocycler Biometra TProfessional (Biometra, Göttingen, Germany) was used. The amplification products were separated in $1.5 \%$ agarose gel electrophoresis running in TAE $1 \times$ at $150 \mathrm{~V}, 25-30$ min and stained with $0.2 \mu \mathrm{g} / \mathrm{ml}$ ethidium bromide (BioRad, Hercules, CA, USA). The $1 \mathrm{~Kb}$ Plus DNA ladder (Invitrogen) was used as a molecular size marker.

Four cyanotoxic genes were assessed with specific primers: 1) $m c y \mathrm{~A}-\mathrm{cd} 1 \mathrm{~F} / m c y \mathrm{~A}-\mathrm{cd} 1 \mathrm{R}$ for microcystin A synthetase (mcyA) (Hisbergues et al., 2003); 2) hep $\mathrm{F} / h e p \mathrm{R}$ for the microcystin/ nodularin aminotransferase (AMT) domain ( $m c y \mathrm{E} /$ ndaF) (Jungblut \& Neilan, 2006); 3) K18/M4 and M13/M14 multiplex PCR for cylindrospermopsin (cyn) (Schembri et al., 2001; Fergusson \& Saint, 2003); and 4) sxtI683F/sxtI877R (sxt1) (V. Ramos, unpublished) and sxtI-F2/sxtI-R (sxt2) (Kellmann et al., 2008a; Brito et al., 2012) for the saxitoxin $(s x t \mathrm{I})$. Each $20 \mu \mathrm{l}$ reaction contained $1 \mu \mathrm{l}$ of $0.5 \mu \mathrm{M}$ of each primer (Invitrogen), $2 \mu \mathrm{l}$ of $0.1 \mu \mathrm{g} / \mu \mathrm{l}$ DNA, $9 \mu \mathrm{l}$ Supreme NZYTaq $2 \times$ Green Master Mix (NZYTech, Lisbon, Portugal) and $7 \mu \mathrm{l}$ of ultrapure sterile water. A negative control (with sterile ultrapure water) and a positive control $(M$. aeruginosa LEGE91094 for the microcystin and microcystin/nodularin genes, $A$. ovalisporum for the cylindrospermopsin gene and A. gracillaris LMECYA 40 from INSA for the saxitoxin gene) were included in each reac- tion. The DNA of the negative cyanotoxic strain Anabaena azollae from the pteridophyte Azolla filiculoides (obtained in the Botanical Garden of Lisbon University) was also included. For all the amplification reactions, an initial denaturation at $95^{\circ} \mathrm{C}$ for $5 \mathrm{~min}$, a final extension at $72^{\circ} \mathrm{C}$ for $7 \mathrm{~min}$ and a hold at $4{ }^{\circ} \mathrm{C}$ were included. The protocols were as follows: 1) 35 cycles of $95^{\circ} \mathrm{C}$ $90 \mathrm{~s}, 56^{\circ} \mathrm{C} 30 \mathrm{~s}, 72^{\circ} \mathrm{C} 50 \mathrm{~s}$ for mcyA; 2) 35 cycles of $92^{\circ} \mathrm{C} 20 \mathrm{~s}, 56^{\circ} \mathrm{C} 30 \mathrm{~s}, 72^{\circ} \mathrm{C} 1 \mathrm{~min}$ for $m c y \mathrm{E} / n d a \mathrm{~F}$; 3) 30 cycles of $94^{\circ} \mathrm{C} 30 \mathrm{~s}, 55^{\circ} \mathrm{C}$ $30 \mathrm{~s}, 72^{\circ} \mathrm{C} 7 \mathrm{~min}$ for cyn; and 4) 35 or 30 cycles of $94{ }^{\circ} \mathrm{C} 10 \mathrm{~s}, 52{ }^{\circ} \mathrm{C} 20 \mathrm{~s}, 72^{\circ} \mathrm{C} 1 \mathrm{~min}$ for sxt 1 and $s x t 2$, respectively.

To identify the cyanobiont, a PCR reaction was performed with the pair of primers $27 \mathrm{~F}$ (Neilan et al., 1997) and CYA781R (Nübel et al., 1997) in $20 \mu \mathrm{l}$ containing $1 \mu \mathrm{l}$ of $0.5 \mu \mathrm{M}$ of each primer (Invitrogen), $2 \mu \mathrm{l}$ of $0.1 \mu \mathrm{g} / \mu \mathrm{l}$ DNA, $9 \mu$ Supreme NZYTaq 2x Green Master Mix (NZYTech) and $7 \mu$ of ultrapure sterile water. The amplification protocol included an initial denaturation at $95^{\circ} \mathrm{C} 5 \mathrm{~min}, 35$ cycles of denaturation at $92^{\circ} \mathrm{C}, 20 \mathrm{~s}$, annealing at $50^{\circ} \mathrm{C}$, $30 \mathrm{~s}$, extension at $72^{\circ} \mathrm{C}, 1 \mathrm{~min}$, with a final extension at $72^{\circ} \mathrm{C} 5 \mathrm{~min}$ and a hold at $4{ }^{\circ} \mathrm{C}$. Negative (with sterile ultrapure water) and positive (M. aeruginosa LEGE91094) controls were included.

The PCR products were cut from the agarose gel and purified with the kit Cut\&Spin Gel Ex-
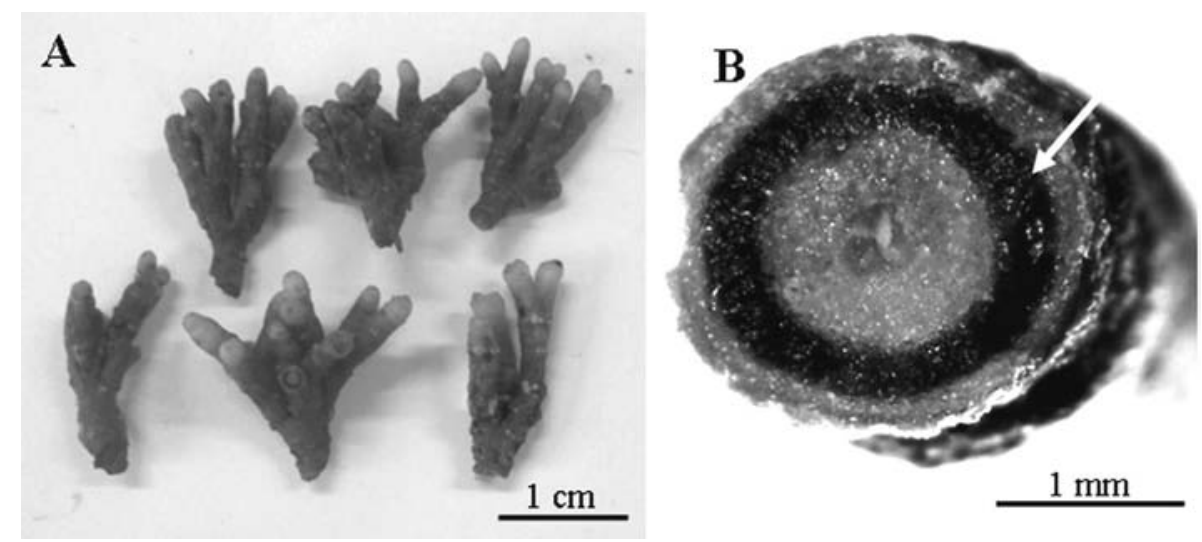

Figure 1. Coralloid roots of Cycas revoluta. (A) Coralloid roots. (B) Transverse section of a coralloid root with a green ring of cyanobacteria (arrow). ). Raíces coraloides de Cycas revoluta. (A) Raíces coraloides. (B) Sección transversal de una raíz coraloide con un anillo verde de cianobacterias (flecha). 
traction Columns (GRiSP, Porto, Portugal) according to the manufacturer's instructions. The positive PCR reactions for cyanotoxins were reamplified and purified as described above. The PCR products were sequenced by Macrogen ${ }^{\circledR}$ (Amsterdam, The Netherlands). To correct mismatches and gaps, the forward and reverse sequences were aligned with the free software $\mathrm{mul}$ tialin 5.4.1 (Corpet, 1988) and matched using BLASTN 2.2.28 (Zhang et al., 2000; Morgulis et al., 2008) on the NCBI database.

\section{RESULTS AND DISCUSSION}

This paper is the first report on the possible presence of cyanobacterial genes involved in the synthesis of toxins by cyanobionts isolated from $\mathrm{Cy}-$ cadales collected in three Portuguese botanical gardens.

The search for cyanotoxic genes in cyanobionts is recent and has primarily been performed in samples of lichens and Cycadales collected in the wild. In cyanolichens belonging to several species collected from all around the world, two hepatotoxins, i.e., nodularin and microcystin, have been detected (Oksanen et al., 2004; Kaasalainen et al., 2012, 2013). In addition, in Nostoc isolated from the coralloid roots of $M$. riedlei and M. serpentine (collected in Australia), the hepatotoxin nodularin was detected (Gehringer $e t$ al., 2012). However, in the cyanobionts isolated from the coralloid roots of several Encephalartos species and $C$. revoluta collected in Portuguese botanical gardens and used in the present research, the genes for microcystin and nodularin were not detected (Fig. 2A). In addition, the gene for cylindrospermopsin (a cytotoxin that inhibits protein synthesis) was also not detected for any of the cyanobionts analysed. These results indicate that the cyanobionts do not have the genes to synthesise the hepatoxins or the cytotoxins. As is also the case in the free-living cyanobacteria, the cyanobiont strains of different Cycadales can be toxic and/or non-toxic, or the cyanobiont strain that synthesises those cyanotoxins can depend on the collection site (wild or botanical gardens). The cyanotoxins (microcystins and nodularin) found in cyanolichens and Macrozamia sp. were identified as products of Nostoc

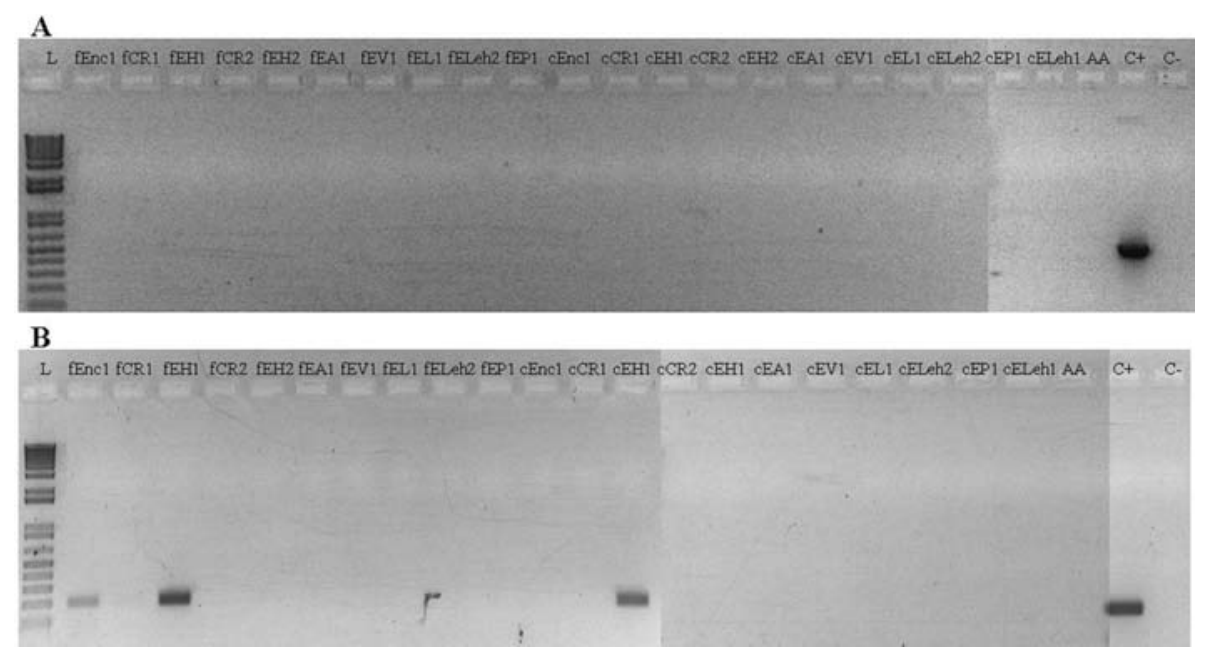

Figure 2. Agarose gel of the amplification for both fresh and cultured symbiotic cyanobacteria isolated from several Cycadales collected at three botanical gardens. (A) Aminotrasferase (AMT) domain of microcystin and nodularin. (B) Saxitoxin gene using the primers sxtI683F/sxtI877R. L, ladder; AA, A. azollae; C+, positive control; C-, negative control. See Table 1 for cyanobiont accession designation. The letter $\mathrm{f}$ or $\mathrm{c}$ before the accession designation refers to fresh isolated and cultured cyanobionts, respectively. Gel de agarosa de la amplificación para cianobacterias aisladas (frescas y cultivadas) de varias Cycadales cultivadas en tres jardines botánicos. (A) Dominio de aminotransferasa (AMT) de microcistina y nodularina. (B) Gen de la saxitoxina con los cebadores sxtI683F/sxtI877R. L, gradiente; AA, A. azollae; $C+$, control positivo; $C$-, control negativo. Véase la Tabla 1 para la designación de código del cianobionte. La letra fo c antes del código se refiere a cianobiontes aisladas frescas y cultivadas, respectivamente. 
(Oksanen et al., 2004; Gehringer et al., 2012; Kaasalainen et al., 2012, 2013), a genus that has both toxic and non-toxic strains. In our research, the cyanobionts isolated from all the coralloid roots of Cyacadales were identified as Nostoc by the BLASTN of the $16 \mathrm{~S}$ gene (unpublished results).

The saxitoxins are neurotoxins produced by a few marine and freshwater cyanobacteria. Only recently has it been possible to sequence the complete saxitoxin gene cluster. One of the genes $-s x t \mathrm{I}-$ encodes the enzyme $O$-carbamoyltransferase (OCTASE), which transfers a carbamoyl group for a compound having a hydroxyl group, such as the saxitoxin precursor (Kellmann et al., 2008a, 2008b; Moustafa et al., 2009; Al-Te- brineh et al., 2010; Murray et al., 2011). In the present research, three cyanobionts -a fresh isolate from Encephalartos sp. (fEnc1) collected in the Porto botanical garden and fresh and cultured isolates from E. horridus (fEH1 and $\mathrm{cEH} 1$ ) collected in the Coimbra botanical gardenshowed positive amplification for the $s x t \mathrm{I}$ gene with the pair of primers sxtI862F/sxtI877R (Fig. 2B). The BLASTN of the nucleotide sequences in the NCBI database, indicate the presence of the $\operatorname{sxtI}$ gene due to their homology with the sxt I gene of the free-living cyanobacteria Aphanizomenon and Cylindrospermosis raciborskii (Table 2). However, the DNA of the same samples did not amplify with the pair of primers $s x t \mathrm{I}-\mathrm{F} 2 / s x t \mathrm{I}-\mathrm{R}$, which amplifies a larger fragment

Table 2. The homologies for the saxitoxin gene with the BLASTN of the three cyanobionts isolated from three Cycadales. Las homologías para el gen de la saxitoxina con el BLASTN de los tres cyanobiontes aislados a partir de tres Cycadales.

\begin{tabular}{|c|c|c|c|c|}
\hline Accession $^{a}$ & BLASTN isolate match and gene & NCBI reference & Homology & E-value \\
\hline \multirow[t]{5}{*}{ fENC1 } & $\begin{array}{l}\text { Aphanizomenon flos-aquae } \mathrm{NH}-5 \text {, } \\
\text { O-carbamoyltransferase (sxt1) }\end{array}$ & EU439559 & $81 \%$ & $2 \mathrm{e}-31$ \\
\hline & Aphanizomenon sp. NH-5, $\mathrm{PSP}^{b}$ & EU603710 & $81 \%$ & $2 \mathrm{e}-31$ \\
\hline & $\begin{array}{l}\text { Cylindrospermosis raciborskii CENA305, } \\
\text { O-carbamoyltransferase (sxt1) }\end{array}$ & KC894589 & $77 \%$ & $4 \mathrm{e}-18$ \\
\hline & $\begin{array}{l}\text { Cylindrospermosis raciborskii CENA302, } \\
\text { O-carbamoyltransferase (sxt1) }\end{array}$ & JX175232 & $77 \%$ & $4 \mathrm{e}-18$ \\
\hline & $\begin{array}{l}\text { Cylindrospermosis raciborskii } \mathrm{T} 3 \text {, } \\
\text { O-carbamoyltransferase (sxt1) }\end{array}$ & EU439556 & $77 \%$ & $4 \mathrm{e}-18$ \\
\hline \multirow[t]{5}{*}{ fEH1 } & $\begin{array}{l}\text { Aphanizomenon flos-aquae } \mathrm{NH}-5 \text {, } \\
\text { O-carbamoyltransferase (sxt1) }\end{array}$ & EU439559 & $81 \%$ & $2 \mathrm{e}-30$ \\
\hline & Aphanizomenon sp. NH-5, $\mathrm{PSP}^{b}$ & EU603710 & $81 \%$ & $2 \mathrm{e}-30$ \\
\hline & $\begin{array}{l}\text { Cylindrospermosis raciborskii CENA305, } \\
\text { O-carbamoyltransferase (sxt1) }\end{array}$ & KC894589 & $77 \%$ & $1 \mathrm{e}-17$ \\
\hline & $\begin{array}{l}\text { Cylindrospermosis raciborskii CENA302, } \\
\text { O-carbamoyltransferase (sxt1) }\end{array}$ & JX175232 & $77 \%$ & $1 \mathrm{e}-17$ \\
\hline & $\begin{array}{l}\text { Cylindrospermosis raciborskii } \mathrm{T} 3 \text {, } \\
\text { O-carbamoyltransferase }(\mathrm{sxt} 1)\end{array}$ & EU439556 & $77 \%$ & $1 \mathrm{e}-17$ \\
\hline \multirow[t]{5}{*}{ cEH1 } & $\begin{array}{l}\text { Aphanizomenon flos-aquae NH-5, } \\
\text { O-carbamoyltransferase (sxt1) }\end{array}$ & EU439559 & $81 \%$ & $1 \mathrm{e}-33$ \\
\hline & Aphanizomenon sp. NH-5, $\mathrm{PSP}^{b}$ & EU603710 & $81 \%$ & $1 e-33$ \\
\hline & $\begin{array}{l}\text { Cylindrospermosis raciborskii CENA305, } \\
\text { O-carbamoyltransferase (sxt1) }\end{array}$ & KC894589 & $77 \%$ & $6 e-21$ \\
\hline & $\begin{array}{l}\text { Cylindrospermosis raciborskii CENA302, } \\
\text { O-carbamoyltransferase (sxt1) }\end{array}$ & JX175232 & $77 \%$ & $6 e-21$ \\
\hline & $\begin{array}{l}\text { Cylindrospermosis raciborskii } \mathrm{T} 3 \text {, } \\
\text { O-carbamoyltransferase }(\mathrm{sxt} 1)\end{array}$ & EU439556 & $77 \%$ & $6 e-21$ \\
\hline
\end{tabular}

${ }^{a} \mathrm{fENC1}$, cyanobiont fresh isolate from the coralloid roots of Encephalartos sp.; fEH1, cyanobiont fresh isolate from the coralloid roots of Encephalartos horridus; cEH1, cyanobiont cultured from the coralloid roots of Encephalartos horridus.

${ }^{b}$ PSP, paralytic shellfish poisoning. 
of the sxtI gene. In addition, the saxitoxin was not detected in any strain of free-living Nostoc. The enzyme $O$-carbamoyltransferase (OCTASE), besides being identified in the gene cluster of the saxitoxin is also related to the biosynthesis of nodulation factors and of other secondary metabolites, such as antibiotics (Kellmann et al., 2008a; Parthier et al., 2012). Perhaps, in the case of the cyanobionts fEnc1, fEH1 and cEH1, the homology with the OCTASE gene may indicate that the cyanobionts synthesise other secondary compounds in which the OCTASE enzyme is required.

In conclusion, the cyanobionts from $\mathrm{Cy}$ cadales grown in three Portuguese Botanical Gardens do not have the genes to synthesize the cyanotoxins nodularin, microcystin and cylindrospermopsin. However, one cyanobiont isolated from the coralloid roots of Encephalartos sp. (fEnc1) and two from E. horridus (fEH1 and cEH1) showed amplification for the saxitoxin gene. As the saxitoxin was not identified in freeliving Nostoc strains, it is necessary to conduct more research on the DNA samples isolated in the present study that were positive for saxitoxin.

\section{ACKNOWLEDGEMENTS}

This research was partially supported by the European Regional Development Fund (ERDF) through the COMPETE-Operational Competitiveness Programme and national funds through FCT-Foundation for Science and Technology, under the project "PEst-C/MAR/LA0015/2013" and by the Project MARBIOTECH (reference NORTE-07-0124-FEDER-000047), co-financed by the North Portugal Regional Operational Programme (ON.2-O Novo Norte), under the National Strategic Reference Framework (NSRF), through the European Regional Development Fund (ERDF). The European Social Funding (FSE) under the Human Potential Operational Program (POPH) of National Strategic Reference Board (QREN) supported fellowship SFRH/BPD/44459/2008 to Ana L. Pereira. We thank to Prof. Teresa Andresen (Botanical Garden of Porto), Dr. Catarina Schreck Reis and Prof. Helena Freitas (Botanical Garden of Coimbra) and Dr. Maria Cristina Duarte (Tropical Botanical Garden, Lisbon) for permission to collect coralloid roots of Cycas revoluta and Encephalartos from the living collections.

\section{REFERENCES}

AL-TEBRINEH, J., T. K. MIHALI, F. POMATI \& B. A. NEILAN. 2010. Detection of saxitoxinproducing cyanobacteria and Anabaena circinalis in environmental water blooms by quantitative PCR. Applied and Environmental Microbiology, 76: 7836-7842.

BRITO, Â., V. RAMOS, R. SEABRA, A. SANTOS, C. L. SANTOS, M. LOPO, S. FERREIRA, A. MARTINS, R. MOTA, B. FRAZÃO, R. MARTINS, V. VASCONCELOS \& P. TAMAGNINI. 2012. Culture-dependent characterization of cyanobacterial diversity in the intertidal zones of the Portuguese coast: A polyphasic study. Systematic and Applied Microbiology, 35: 110-119.

CORPET, F. 1988. Multiple sequence alignment with hierarchical clustering. Nucleic Acids Research, 16: 10881-10890.

COSTA, J. -L., P. PAULSRUD \& P. LINDBLAD. 1999. Cyanobiont diversity within coralloid roots of selected cycad species. FEMS Microbiology Ecology, 28: 85-91.

FERGUSSON, K. M. \& C. P. SAINT. 2003. Multiplex PCR assay for Cylindrospermopsis raciborskii and cylindrospermopsin-producing cyanobacteria. Environmental Toxicology, 18: 120-125.

GEHRINGER, M. M., J. J. L. PENGELLY, W. S. CUDDY, C. FIEKER, P. I. FORSTER \& B. A. NEILAN. 2010. Host selection of symbiotic cyanobacteria in 31 species of the Australian cycad genus: Macrozamia (Zamiaceae). Molecular Plant-Microbe Interactions, 23: 811-822.

GEHRINGER, M. M., L. ADLER, A. A. ROBERTS, M. C. MOFFITT, T. K. MIHALI, T. J. T. MILLS, C. FIEKER \& B. A. NEILAN. 2012. Nodularin, a cyanobacterial toxin, is synthesized in planta by symbiotic Nostoc sp. ISME Journal, 6: 1834-1847.

HISBERGUES, M., G. CHRISTIANSEN, L. ROUHIAINEN, K. SIVONEN \& T. BÖRNER. 2003. PCR-based identification of microcystinproducing genotypes of different cyanobacterial genera. Archives of Microbiology, 180: 402-410. 
JUNGBLUT, A. -D. \& B. A. NEILAN. 2006. Molecular identification and evolution of the cyclic peptides hepatotoxins, microcystin and nodularin, synthetase genes in three orders of cyanobacteria. Archives of Microbiology, 185: 107-114.

KAASALAINEN, U., D. P. FEWER, J. JOKELA, M. WAHLSTEN, K. SIVONEN \& J. RIKKINEN. 2012. Cyanobacteria produce a high variety of hepatotoxic peptides in lichen symbiosis. Proceedings of the National Academy of Sciences USA, 109: 5886-5891.

KAASALAINEN, U., D. P. FEWER, J. JOKELA, M. WAHLSTEN, K. SIVONEN \& J. RIKKINEN. 2013. Lichen species identity and diversity of cyanobacterial toxins in symbiosis. New Phytologist, 198: 647-651.

KELLMANN, R., T. K. MICHALI \& B. A. NEILAN. 2008a. Identification of a saxitoxin biosynthesis gene with a history of frequent horizontal gene transfer. Journal of Molecular Evolution, 67: 526538.

KELLMANN, R., T. K. MICHALI, Y. J. JEON, R. PICKFORD, F. POMATI \& B. A. NEILAN. 2008b. Biosynthetic intermediate analysis and functional homology reveal a saxitoxin gene cluster in cyanobacteria. Applied and Environmental Microbiology, 74: 4044-4053.

MEREL, S., D. WALKER, R. CHICANA, S. SNYDER, E. BAURÈS \& O. THOMAS. 2013. State of knowledge and concerns on cyanobacterial blooms and cyanotoxins. Environmental International, 59: 303-327.

MORGULIS, A., G. COULOURIS, Y. RAYTSELIS, T. L. MADDEN, R. AGARWALA \& A. A. SCHÄFFER. 2008. Database indexing for production MegaBLAST searches. Bioinformatics, 24: 1757-1764.

MOUSTAFA, A., J. E. LORAM, J. D. HACKETT, D. M. ANDERSON, F. G. PLUMLEY \& D. BHATTACHARYA. 2009. Origin of saxitoxin biosynthetic genes in cyanobacteria. Plos One, 4: e5758.

MURRAY, S. A., M. WIESE, A. STÜKEN, S. BRETT, R. KELLMANN, G. HALLEGRAEFF $\&$ B. A. NEILAN. 2011. sxtA-based quantitative molecular assay to identify saxitoxin-producing harmful algal blooms in marine waters. Applied and Environmental Microbiology, 77: 7050-7057.

NEILAN, B. A., D. JACOBS, T. DEL DOT, L. L. BLACKALL, P. R. HAWKINS, P. T. COX \& A. E. GOODMAN. 1997. rRNA sequences and evolutionary relationships among toxic and nontoxic cyanobacteria of the genus Microcystis. International Journal of Systematic Bacteriology, 47: 693-697.

NÜBEL, U., F. GARCIA-PICHEL \& G. MUYZER. 1997. PCR primers to amplify 16S rRNA genes from cyanobacteria. Applied and Environmental Microbiology, 63: 3327-3332.

OKSANEN, I., J. JOKELA, D. P. FEWER, M. WAHLSTEN, J. RIKKINEN \& K. SIVONEN. 2004. Discovery of rare and highly toxic microcystins from lichen-associated cyanobacterium Nostoc sp. strain IO-102-I. Applied and Environmental Microbiology, 70: 5756-5763.

PARTHIER, C., S. GÖRLICH, F. JAENECKE, C. BREITHAUPT, U. BRÄUER, U. FANDRICH, D. CLAUSNITZER, U. F. WEHMEIER, C. BÖTTCHER, D.CHEEL \& M. T. STUBBS. 2012. The $O$-carbamoyltransferase TobZ catalyzes an ancient enzymatic reaction. Angewandte Communications International Edition, 51: 4046-4052.

PEARSON, L., T. MIHALI, M. MOFFITT, R. KELLMANN \& B. A. NEILAN. 2010. On the chemistry, toxicology and genetics of the cyanobacterial toxins, microcystins, nodularin, saxitoxin and cylindrospermopsin. Marine Drugs, 8: 1650-1680.

RAI, A. N., E. SÖDERBÄCK \& B. BERGMAN. 2000. Cyanobacterium-plant symbiosis. New Phytologist, 147: 449-481.

RIPPKA, R., J. DERUELLES, J. B. WATERBURY, M. HERDMAN \& R. Y. STANIER. 1979. Generic assignments, strain histories and properties of pure cultures of cyanobacteria. Journal of General Microbiology, 111: 1-61.

SCHEMBRI, M. A., B. A. NEILAN \& C. P. SAINT. 2001. Identification of genes implicated in toxin production in the cyanobacterium Cylindrospermospis raciborskii. Environmental Toxicology, 16: 413-421.

THAJUDDIN, N., G. MURALITHARAN, M. SUNDARAMOORTHY, R. RAMAMOORTHY, S. RAMACHANDRAN, M. A. AKBARSHA \& M. GUNASEKARAN. 2010. Morphological and genetic diversity of symbiotic cyanobacteria from cycads. Journal of Basic Microbiology, 50: 254-265.

USHER, K. M., B. BERGMAN \& J. A. RAVEN. 2007. Exploring cyanobacterial mutualisms. Annual Review of Ecology, Evolution and Systematics, 38: 255-273.

WIEGAND, C. \& S. PFLUGMACHER. 2005. Ecotoxicological effects of selected cyanobacterial 
secondary metabolites: a short review. Toxicology and Applied Pharmacology, 203: 201-218.

YAMADA, S., S. OHKUBO, H. MIYASHITA \& H. SETOGUCHI. 2012. Genetic diversity of symbiotic cyanobacteria in Cycas revoluta (Cycadaceae). FEMS Microbiology Ecology, 81: 696-706.
ZHANG, Z., S. SCHWARTZ, L. WAGNER \& W. MILLER. 2000. A greedy algorithm for aligning DNA sequences. Journal of Computational Biology, 7: 203-14.

ZONNEVELD, B. J. M. 2012. Genome sizes for all genera of Cycadales. Plant Biology, 14: 253-256. 